\title{
HOMENAGENS
}

\section{PROF. OTMAR FREIHERR VON VERSCHUER}

A data de 16 de julho assumiu no corrente ano significado particular para todos os centros em que se cultiva a Genética Humana. O Professor Otmar Freiherr von Verschuer, atualmente em Münsingen, Westrália, completou então 60 anos, dos quais mais de 33 têm sido consagrados à pesquisa cientifica.

Nascido em Rotenburg, perto de Fulda, na circunscriçāo de Hessen, em 1896, obteve em München o diploma de médico em 1922 e o grau de doutor em medicina em 1923. Nêsse mesmo ano foi nomeado primeiro assistente de Clínica Médica na Universidade de Tübingen, votando-se desde logo as pesquisas em gemelologia. Quatro anos mais tarde conquistava a docência livre, com a tese sôbre "a pesquisa heredobiológica sôbre gêmeos". Ainda em 1927 foi escolhido para dirigír a secçāo de Genética Humana do "Institut für Anthropologie, menschliche Erblehre und Eugenik", então recem-fundado em Berlim-Dahlem por Eugen Fischer. Após proficua atividade, que desde logo se refletiu no cenário mundial, foi nomeado professor extraordinário de genética humana em 1933; e quase a seguir, 1935, na qualidade de professor ordinário dessa disciplina, passou para a Universidade de Frankfurt am Main, dirigindo ai o "Universitäts-Institut für Erbbiologie und Rassenhygiene". Com a aposentadoria de Fischer, em 1942, voltou von Verschuer para o célebre Instituto de Berlin-Dahlem, agora com a honrosa distinçāo de suceder ao mestre naquela direçāo; manteve-se assim sem soluçāo de continuidade o alto padrão daquêle centro de primeira grandeza, até que - com o têrmino da guerra mundial - foi dissolvido, em 1945. Ainda nesta conjuntura o homenageado prestou relevante serviço ao mundo cientifico, salvaguardando o precioso cabedal bibliográfico e documentário daquela institulção, até que pôde reencetar o ensino e a pesquisa sistemáticos da genética médica, cêrca de um Iustro depois. Efetivamente, na poderosa circunscrição da Westfália, a Universidade de Münster instituia em 1951 o ensino da genética humana e lhe confiava ao mesmo tempo o cargo de professor ordinário e a direção do "Institut für Humangenetik".

Da nutrida produção eientifica de von verschuer e de colaboradores e discipulos, a qual atinge a cêrca de duas centenas - entre publicaçōes isoladas, monografias e livros - , vale mencionar algumas obras que marcam direções especiais: 1. Die vererbungsbiologische Zwillingsforschung. Ihre blologischen Grundlagen. Studien an 102 eineligen und 45 gleichgeschlechtigen zweieilgen Zwillings und an 2 Drillingspaaren, Tübingen, 1927; 2, Zwillingstuberkulose,1. Band (mit K. Diehl). Fischer, Jena, 1933; 3. Der Erbeinfluss bei der Tuberkulose, 2. Band (mit $\mathrm{K}$. Dieh1). Fischer, Jena, 1936; 4. Erbpathologie, 2, Aufl, Steinkoptf, Leipzig, 1937 (1. Aufl. 1934); 5. Leitfaden der Rassenhygiene, 2. Aufl. Georg Thieme, Leipzig, 1943; 6. Die Anwendung von Erkenntnissen der allgemeinen Genetik auf den Menschen und ihre Grenzen. Steiner, Wiesbaden, 1950; 7. Wirksame Faktoren im Leben des Menschen. Beobachtungen an ein- und zweieiigen Zwillingen durch 25 Jahre. Steiner, Wiesbaden, 1954. Em relevantes contribuições para tratados sỏbre a especialidade, firmou igualmente a marca pessoal das próprías concepcōes: entre os que conhecemos, nos de Just, Vererbung und Erziehung (1930), de Baur-FischerLenz, Menschliche Erblehre und Rassenhygiene (1940), de Seitz-Amreich, Biologie und Pathologie des Weibes (1953).

Essas publicações refletem a originalidade e ao mesmo tempo a fertilidade características da obra genética de von Verschuer e da escola por èle organizada. Apurou o estudo heredobiológico dos gêmeos, de modo a erigi-lo em método de pes- 
quísa no domínio da genética humana. E hoje inconteste que o elevado grau de concordáncia intra-geminal nos pares monozigóticos quanto a determinado traço, quando comparada à concordância em pares dizigóticos, revela a natureza genétíca do traço. E que a não especificidade na concordância atesta a origem ambiencial da manifestação em causa. Mesmo para esta avaliação relativa o eminente geneticista contribuiu com elementos fundamentais: no critério para o confronto donde o diagnóstico da zigoticidade - remodelou os dados comparativos de Siemens, organizando assim a escala que é hoje conhecida em todos os centros sob o nome de ambos os autores, e largamente utilizada; para a análise das concordâncias e das discordâncias desenvolveu förmulas matemáticas, também unânimemente aceitas; e finalmente pôde mostrar que numerosas interferências ambienciais na configuração fenotípica do individuo humano - do gêmeo no caso particular resultam, em última análise, de tendência genética.

A heredopatologia constituiu desde o inicio objeto de aprofundadas investigações de von Verschuer, as quais, como acentua C. F. Mayer ${ }^{3}$, constituem "os guias básicos da patologia hereditária e da eugenia na Alemanha". Nêsse campo em particular, a disposição genética para doencas somáticas, para sensibilidade aos fatôres infecciosos, tanto quanto para as malrormacões corporais tem sido claramente demonstrada no amplo material clínico tão magistralmente explorado.

Ainda em relação ao problema gemelológico decorrem da obra do biografado deduçōes de grande alcance. Nāo só o próprio fenómeno da geminação pode ser reconhecido como resultante de fator genético, mas ainda se evidenciou ser desta natureza a ocorrência - aparentemente ocasional - de gêmeos dizigóticos: a suscetibilidade a êstes fatôres ocasionáis em atuação seria caso particular das disposiçōes genéticas a que aludimos no parágrafo anterior. Por sua vez, a semelhança entre gêmeos concordantes monozigóticos pode ser mascarada por fatôres adquiridos no decurso da vida. E extraordinàriamente sugestiva e cheia de ensinamentos a aprecjação de numerosos pares de gẽmeos — de ambas as modalidades - em sentido longitudinal, tal como o fez von Verschuer, no livro que citámos $s u b$ y e em vários artigos, analisando-lhes a evolução já durante 25 anos.

A amplitude e ao mesmo tempo a intensidade das investigaçōes em genética humana grangearam ao ilustre biografado situação de primazia no mundo cientifico. Disto dá bem idéia a largueza com que L. Gedda, na monumental obra "Studio dei Gemelij" ', lhe cita os trabalhos; em 136 páginas do texto, por vêzes em mais de um passo. Compreende-se fàcilmente, dessa fórma, que não nos seria dado em tão rápida apreciação biográfica analisar todos os aspectos, mesmo gerais, dessa imensa contribuição para o conhecimento da personalidade humana. Ademais, a forte cultura geral e a disciplina do espirito que, ao lado do cavalheirismo, caracterizam a von Verschuer fazem ver que tal produtividade se acha no apogeu e que ao certo assim se manterá por dilatado tempo, ampliando-se com a própria escola.

Nesta grata oportunidade têm pleno cabimento os augúrios públicamente formulados por nosso colega e amigo Koch, discipulo e colaborador de von Verschuer, quando lhe comemorou o $55^{\circ}$ aniversário: que «continue por longos anos a fazer prosperar o seu elevado espirito cientifico, a bem da Ciência e da Humanidade." 2

ANfBAL SILVETRA

Referências - 1. GEDDA, L. - Studio del Gemelli. Orizonte Medico, Roma, 1951. 2. KOCH, G. - Otmar Freiherr von verschuer. Vida e obra. O Médico, Porto, No 38, 1952 (separatum). 3. MAYER, C. F. - Genesis of genetics. Acta Genet. Med. Gemellol., 2:237-332, 1953. 